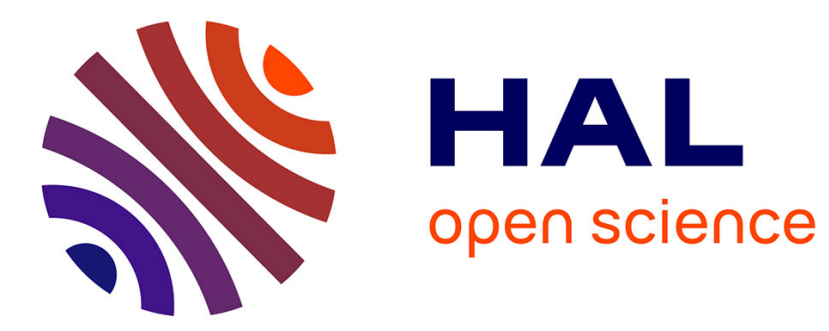

\title{
When family dining protects against sweet food consumption... and when it does not
}

\author{
Marie-Eve Laporte, Sophie Rieunier, Géraldine Michel
}

\section{To cite this version:}

Marie-Eve Laporte, Sophie Rieunier, Géraldine Michel. When family dining protects against sweet food consumption... and when it does not. Journal of Consumer Affairs, 2020, 54 (2), pp.628-647. 10.1111/joca.12293 . hal-02472006

\section{HAL Id: hal-02472006 https://hal.science/hal-02472006}

Submitted on 9 Feb 2020

HAL is a multi-disciplinary open access archive for the deposit and dissemination of scientific research documents, whether they are published or not. The documents may come from teaching and research institutions in France or abroad, or from public or private research centers.
L'archive ouverte pluridisciplinaire HAL, est destinée au dépôt et à la diffusion de documents scientifiques de niveau recherche, publiés ou non, émanant des établissements d'enseignement et de recherche français ou étrangers, des laboratoires publics ou privés. 
When Family Dining Protects Against Sweet Food Consumption... And When It Does Not

Manuscript ID: JOCA-17-1036 R2

\section{Marie-Eve LAPORTE}

IAE Paris 1 Panthéon-Sorbonne (Sorbonne Business School), 8 bis rue de la Croix Jarry, 75013 Paris, France

laporte.iae@univ-paris1.fr

Corresponding author (tel: +33 645027979 )

\section{Sophie RIEUNIER}

IRG - IAE Gustave Eiffel (Université Paris-Est Marne-la-Vallée), 5 rue Galilée, 77420 Champs-sur-Marne, France

sophie.rieunier@u-pem.fr

\section{Géraldine MICHEL}

IAE Paris 1 Panthéon-Sorbonne (Sorbonne Business School), 8 bis rue de la Croix Jarry, 75013 Paris, France

michel.iae@univ-paris1.fr 


\title{
When Family Dining Protects Against Sweet Food Consumption... And When It Does Not
}

\begin{abstract}
The World Health Organization recommends reducing sugar intake in order to improve one's health. In this spirit, the aim of the present research is to test the impact that dining as a family has on the consumption of sweet food and to compare the results with the impact of dining alone or with friends, at home or away. A mixed-method design was employed and combines an experiment with a descriptive survey. The results show that family dining at home tends to foster healthier eating behavior by restricting sweet food consumption, while dining alone or with friends at home may lead more easily to the consumption of sweet foods. However, this protective effect of family dining does not hold outside the home. This study helps explain the apparent contradictions in the literature regarding how the presence of others influences food intake. It provides guidance to policy and business stakeholders, such as health agencies, public authorities, food and catering industries, and food distributors, on ways to reduce sugar consumption and, consequently, to improve consumers' eating behaviors.
\end{abstract}

\section{INTRODUCTION}

Improving people's eating behaviors is a priority for public health authorities because of the alarming costs (in both human and economic terms) of certain eating behaviors. It also concerns food producers and distributors as they have been accused of contributing to unhealthy eating (Moore and Rideout 2007; Moss 2013). According to the World Health Organization, noncommunicable diseases ${ }^{1}$ are to blame for 40 million deaths each year,

1. Henceforth, the World Health Organization and noncommunicable diseases are referred to by their respective abbreviations, WHO and NCDs. 
together comprising $70 \%$ of all fatalities worldwide (WHO 2017). The links between nutrition and most NCDs - including cardio-vascular disease, obesity, type 2 diabetes, and certain types of cancer - have been well established and demand action (WHO 2013a; WHO and FAO 2003). For this reason, the ministers of health and member states of the WHO in Europe signed the "Vienna Declaration on Nutrition and Noncommunicable Diseases [NCDs] in the Context of Health 2020," in which they "reaffirm [their] commitment (...) to address important NCD risk factors, notably unhealthy diet and physical inactivity" (WHO 2013b). In particular, the WHO strongly recommends reducing the daily consumption level of free sugars to less than $10 \%$ (ideally $5 \%$ ) of one's total energy intake, as high levels of free sugar intake are a major risk factor for obesity and other NCDs (WHO 2015). As for the economic impacts of unhealthy eating, obesity alone costs "around \$2 trillion annually, or 2.8 percent of global gross domestic product - nearly equivalent to the global impact of smoking, or of armed violence, war, and terrorism," according to a McKinsey report (Dobbs et al. 2014).

Still, considerable resources have been devoted to nutritional education on the assumption that increasing nutritional knowledge would improve eating behaviors. However, reality has proved otherwise. For instance, even though Americans have far better nutritional knowledge than the French, their nutritional behaviors are less healthy (Saulais et al. 2012). Cultural and social approaches to food may help explain this "[other] French paradox" (Saulais et al. 2012). Indeed, the French place considerable emphasis on "commensality" (literally, sharing the table with other persons) - a notion highlighted by many food sociologists (Boutaud 2004; Fischler 2011; Fischler and Masson 2008; Poulain 2002, 2012; Rozin 2005; Rozin et al. 2003). Eighty-five percent of French households (comprising at least two people) typically have dinner together, most of the time with family members and at home (Hébel 2012). Although it seems to be happening less and less, eating together as a family is a common trend among Mediterranean countries, including Italy, Spain, and the Maghreb countries 
(Fischler 2013; Masson, Bubendorff, and Fraïssé 2018). It is also common in many parts of Asia (Yu, Veeck, and Yu 2015). By contrast, people tend to eat alone more often in the USA, the UK, and Scandinavia (Fischler and Masson 2008; Pollan 2009; Sobal and Nelson 2003) and do so more frequently away from home $-30 \%$ of the 5.5 daily meals in the USA, as opposed to $16 \%$ of the 3.9 daily meals in France (Mathé et al. 2011). At the same time, food habits in Europe have changed a lot in recent years. They have become more individualized, and new forms of meal sharing using digital tools, such as eating communities, have appeared (Masson, Bubendorff, and Fraïssé 2018).

Do individuals eat more healthily when they share their everyday meals with family members? Does it matter whether people eat at home or not? Literature has not provided definitive answers to these questions. While previous research has shown that eating in groups does influence food intake as opposed to eating alone, the direction of the effect changes depending on the theoretical framework used. According to social facilitation theory, people eat more when they are in groups, while impression management theory indicates they eat less in such circumstances. As for modeling process theory, it says that either effect is possible, since people model others' behavior. However, it does not take into account where the meal takes place.

Using these different theories, as well as Belk's (2010) typology of sharing, the present research offers an alternative approach to nutritional education, at least for people who do not live on their own. ${ }^{2}$ Its objective is to improve food behavior and, more specifically, limit sweet food consumption as per the WHO's recommendations (WHO 2015). Indeed, according to Burton et al. (2014), many studies focus on calories (see, for instance, Harris and Thomas

2. In fact, most people do not live alone: In 2015, 85\% of the world's 2 billion households consisted of two or more people. It should be noted, however, that the number of one-person households is on the rise, with the highest rate in Europe and Japan (around one-third of their households, up to $40 \%$ in northern Europe), due in particular to an aging demography. In North America, the level of one-person households is around $28 \%$. It is much lower in developing countries (15\% in China, between 4 and 5\% in India and Pakistan). Source: Eurostat, OECD, and national estimates, http://www.ipsnews.net/2017/02/the-rise-of-one-person-households. 
2017), when other nutritional factors can affect health, such as sodium or sugar levels, and therefore ought to receive more attention. The study by Burton et al. (2014) concentrates on sodium; ours focuses on sugar.

In terms of methodology, an experiment (Study 1) and a descriptive survey (Study 2) are conducted. This mixed-method design makes it possible to "account for both controlled experimental findings and other, more 'real-world' oriented results" (Hieke and Taylor 2012). In accordance with impression management principles (Herman, Roth, and Polivy 2003), our research shows that family dining at home involves levels of nutritional risk taking that are lower than when dining alone or with friends. However, this family protection effect is no longer present outside the home. The study has social and managerial implications for policy and business stakeholders, such as health agencies, public authorities, food and catering industries, and food distributors, as it provides better-informed and more meaningful guidance on ways to reduce sugar consumption.

\section{THEORETICAL BACKGROUND}

\section{Anticipated Role of Sharing Meals}

According to anthropologists, eating has played a key role in the evolution of mankind as a result of its deep connection to social life (Mintz and Du Bois 2002; Picq 2004). Eating is not just the ingestion of food; it is also shaped by consumption conditions. Several theoretical frameworks that are used in the public health sphere to predict behaviors consider the normative role that a group plays, including the theory of reasoned action (Ajzen and Fishbein 1980; Fishbein and Ajzen 1975), the theory of planned behavior (Ajzen 1991), and social cognitive theory (Bandura 1977; Hawley, Harker, and Harker 2010). According to these theories, subjective norms or "perceived social pressures" explain the intentions to adopt a 
behavior or not in addition to attitudes toward such behaviors and perceived control according to the theory of planned behavior. The role of perceived social pressure has been verified for numerous contexts, including for contexts of food behavior (Povey et al. 2000). As a result, meal sharing can be expected to have an impact on food behavior.

However, the effects of commensality on food behavior are unclear, and the results from existing research appear to be contradictory. Herman, Roth and Polivy (2003) attempted to reconcile such results by showing that they depend on the theoretical frameworks used: (1) Some studies have found that people eat more when they are dining as part of a group than when they are alone because group meals last longer and the presence of others diverts attention from the action of eating (Bell and Pliner 2003; De Castro 2010; Hetherington et al. 2006; Pliner et al. 2006; Stroebele and De Castro 2004). As a result, people tend to eat mindlessly and lose track of time and the amount of food they eat (Hetherington et al. 2006). Such studies use social facilitation as a theoretical framework. (2) Other studies have found that certain individuals eat less in such situations. For instance, women eat fewer calories in the presence of men (Allen-O'Donnell et al. 2011; Herman, Roth, and Polivy 2003; Mori, Chaiken, and Pliner 1987). Indeed, women feel that they are evaluated with regard to their femininity, and as a result they refrain from eating. In this case, the framework used is that of impression management, "assum[ing] that variations in intake are intended to convey a desired impression to others (and perhaps secondarily to enhance one's self-image)" (Herman, Roth, and Polivy 2003). (3) Finally, according to some studies, the presence of others either fosters or deters overeating, depending on how the people are evaluated. When individuals estimate they are similar to others or aspire to be similar to them, they model others' eating behaviors (Cruwys, Bevelander, and Hermans 2015). In particular, the amount that others eat helps consumers determine their own food portions by taking others' body size into account (McFerran et al. 2013). This modeling process, which can be either positive or negative, is 
used to limit uncertainty and facilitate decision making. A meta-analysis shows that modeling is robust and can be considered "one of the most powerful social influences on food intake" (Vartanian et al. 2015). It illustrates the complex effects of meal sharing on food behavior, as "people adjust their food intake to that of their eating companion, eating a little when their companion eats a little, and eating more when their companion eats more". Depending on the factor that is isolated, meal sharing can then either increase or decrease food intake (De Castro 2010).

In the case of sugar consumption, an unhealthy diet factor in public policies (WHO 2015), the role of social contexts may be even more salient. Studies have shown that high-calorie sweet foods tend to be eaten as comfort food, particularly by women (Dubé, LeBel, and Lu 2005). Eating such food helps people "alleviate negative affects under stressful conditions" (Dubé, LeBel, and Lu 2005), even though it can also make individuals feel guilty. Comfort food seems to be eaten more specifically when people feel lonely or their sense of belonging is threatened (Troisi et al. 2015).

\section{Hypotheses}

To address such complexities, the present study concentrates on dining contexts. It focuses on sweet food consumption patterns in utilitarian situations, excluding festive occasions such as celebratory meals. The research objective is to improve everyday food behavior and, more specifically, to limit the consumption of free sugars, as the WHO (2015) recommends. It investigates meals at home, which represents $80 \%$ of all meals in France (de Saint Pol and Ricroch 2012), by using a mixed-method approach to increase the levels of external validity: an experimental design for Study 1 and a descriptive survey for Study 2. Study 2 extends the study to meals had away from home. 
For an everyday meal at home with immediate family members, such as one's parents, partner, and/or children, individuals should feel prompted to adopt nutritional behaviors that comply with social norms in accordance with impression management research principles (Herman, Roth, and Polivy 2003). Indeed, their behavior is "subject to public scrutiny" (Wang, Zhu, and Shiv 2012). They will feel observed by family members whom they are used to dining with and whose opinion matters to them (Fischler 2011; Laporte, Michel, and Rieunier 2015). They are expected to try to avoid being subjected to negative judgments, especially regarding their choice of dessert. They reinforce this process by modeling their eating companions' behaviors (McFerran et al. 2013); everyone tries to appear as virtuous as the others and wants to conform to the majority (Wang, Zhu, and Shiv 2012). Moreover, because they are less likely to feel lonely when dining with members of their immediate family, their propensity to turn to sweet food as comfort food should be relatively low (Troisi et al. 2015)

Hence, the following hypothesis is proposed:

- H1: Sharing meals at home with one's immediate family involves a lower intention to indulge in sweet desserts than the tendencies observed when dining alone at home.

A different pattern is expected when people eat at home with friends. Unlike family dining, it is no longer an act of sharing as conceptualized by Belk (2010). Indeed, sharing generally "goes unnoticed and is invisible to most people for whom it is routine" (Belk 2010). For Belk (2010), a family meal within the home is a prototype of sharing because it is "an act of caring as well as an act of nurturing." By contrast, dining with friends is closer to gift giving since it is not a routine situation and does not go unnoticed; rather, it is "acknowledged with verbalized thanks" (Belk 2010). Based on Mauss's analysis of primitive societies (1925) and as opposed to sharing, gift giving also creates an expectation of a reciprocal gift in practice 
"because we are caught up in a system of mutual obligations" (Belk 2010). This is why people invited to eat at their friends' house often bring along something to drink or eat or give flowers. Moreover, it is expected that they return the invitation at a later stage.

As a result, when having friends over for lunch or dinner at one's home, the food should be abundant in order to demonstrate generosity and hospitality. Owing to principles of social facilitation (Bell and Pliner 2003; De Castro 2010; Hetherington et al. 2006; Pliner et al. 2006; Stroebele and De Castro 2004), it should lead individuals to enjoy without restraint and set nutritional rules aside. Moreover, if the invitees have brought food with them, it would be rude not to eat what typically turns out to be an indulgent sweet dessert or chocolates. With everyone encouraging one another to make the most of the moment, social modeling (McFerran et al. 2013) should further contribute to people eating richer food and in larger quantities than usual. This effect is expected not just for celebratory events, which are classical cases of gift giving, but also for non-festive occasions and even when friends drop by unexpectedly. Such situations can happen quite regularly when people live with roommates. In Belk's classification, these are acts of "sharing out": People divide their resource - here, the food - while preserving their own boundaries or the boundaries of their immediate family seen as an extended self (Belk 2010). Still, according to Belk (2010), sharing out is in effect very close to gift giving. Therefore, we expect the influence on eating behavior to be similar.

Consequently, it makes sense to assume the following:

- H2: Sharing meals at home with one's immediate family involves a lesser intention to indulge in sweet desserts than the tendencies observed when dining at home with friends. 
These relationships could be moderated by the location where a meal is eaten (at home or away from home), which leads to a third hypothesis - one that will be presented later and investigated in Study 2.

\section{STUDY 1: THE INFLUENCE OF FAMILY DINING AT HOME}

Three dining conditions were manipulated (dinner had alone vs. with immediate family members vs. with friends) in a between-subjects experiment while using an at-home meal scenario to test hypotheses 1 and 2 (see Table 1).

[Insert Table 1 about here]

\section{Methods of Study 1}

In this study, 134 online questionnaires, which had first been pretested with 13 individuals, were completed by individuals aged 25-70. Only women were selected to participate, as women are more frequently in charge of food consumption decisions and are more sensitive to nutritional risks (Grunert and Wills 2007; Zingg et al. 2013; Hassan, Shiu, and Michaelidou 2010; Hieke and Newman 2015; Nayga 2000). Data was collected throughout France by using the SurveyMonkey Audience consumer database and selecting individuals of various household sizes, education levels, household locations, socio-professional categories, and ages (44.7 years on average). Table 2 offers a description of the sampled profile.

[Insert Table 2 about here] 
Respondents were randomly assigned to one of the three conditions of the following dinner-at-home scenario. It is important to note that in France, as in many other countries, the norm is to finish the meal on a sweet note: ${ }^{3}$

"You have just come home on a weekday evening.

(1) You're having dinner by yourself. At dessert time, you open the fridge.

(2) You're having dinner with your family. At dessert time, you open the fridge.

(3) You start having dinner by yourself when, at dessert time, the doorbell rings. A couple of very good friends have dropped by. You casually offer that they have dessert with you, and you open the fridge.

You see there is fruit salad and chocolate mousse."

The respondents were then asked to what extent they intended to eat the chocolate mousse. This dependent variable was measured on a seven-point Likert scale. Chocolate mousse was chosen as dessert for the following reasons: First, it is one of the most popular desserts in France (Kantar TNS 2012); people buy it in multipacks of individual pots from the supermarket's yoghurt aisle, or they prepare it themselves. Second, because of its high sugar content, it is judged to be rather unhealthy. Third, it is often considered a comfort food, especially by women (Dubé, LeBel, and Lu 2005). The perception of chocolate mousse as unhealthy was confirmed by the pretest and by an ex-post measure on a seven-point Likert scale ("eating this dessert every day would be unhealthy"), which shows that chocolate mousse is viewed as significantly less healthy than fruit salad, which was the counter-example $\left(M_{\text {chocolate }}\right.$ mousse $\left.=5.10, S E_{\text {chocolate mousse }}=1.49, M_{\text {fruit salad }}=2.02, S E_{\text {fruit salad }}=1.20, p<.001\right)$.

3. For instance, the French usually have dessert at the end of a meal, but it is not necessarily an indulgent one. In most cases, it is a piece of fruit, according to a 2017 report by the French Agency for Food, Environmental and Occupational Health and Safety (INCa3), which based its findings on data collected from more than 5,800 individuals. In France, out of the total solid quantity of food eaten by adults every day in France, dessert accounts for $17 \%$, of which $43 \%$ are fruit and nuts, $25 \%$ yoghurt, $32 \%$ dessert such as cakes and pastries, mousses, and cream desserts (https://www.anses.fr/en/content/inca-3-changes-consumption-habits-and-patternsnew-issues-areas-food-safety-and-nutrition). 
Manipulation checks were included at the end of the questionnaire to ensure that the dining condition was properly identified (dessert eaten alone, with friends, with family), and that it was a routine dinner and not a special occasion. A chi-square analysis confirms that all three experimental cells were relatively homogenous in terms of respondent profiles (see Table 2).

\section{Results of Study 1}

An ANOVA was conducted to check whether the differences in the intention to eat chocolate mousse are significant between the three meal conditions (dining alone, with one's family, or with friends), as presented in Table 3. It shows meal conditions have a significant influence on intentions to eat chocolate mousse $(F=4.25, p=.016)$. The intention to eat fruit salad, which was the control variable, did not vary between the groups. The results are the same, regardless of whether we consider the whole set of respondents or exclude those living alone.

\section{[Insert Table 3 about here]}

Planned contrasts indicate that family dining involves a lesser intention to eat indulgent sweet dessert (here, chocolate mousse $\left.\left(M_{\text {family }}=4.38\right)\right)$ than when dining alone $\left(M_{\text {alone }}=4.80\right)$. However, this effect is significant only at a $10 \%$ threshold for confidence $(t(131)=1.84$, $p=.068$ ), so there is not clear support for H1. Compared with dining with friends $\left(M_{\text {friends }}=5.02\right)$, family dining significantly decreases intentions to eat an indulgent sweet dessert $(t(131)=2.88, p=.005)$, which gives strong support for $\mathrm{H} 2$.

Additional analyses were conducted using ANCOVAs to assess covariates' influence on the intention to eat an indulgent sweet dessert. None of them showed any influence: not age $(p=.25)$, household size $(p=.21)$, level of education $(p=.32)$, socio-economic level $(p=.30)$, area (Paris vs rest of France; $p=.44$ ), or home location (big city vs middle-sized city vs countryside; $p=.19$ ). We also measured how usual the dining scenario (dining alone, with 
family, or with friends) was for the interviewees; it did not have an impact on the results $(p=.83)$.

These findings help elucidate the processes of nutritional risk taking that shape food consumption. Family dining seems to limit sweet food consumption and, thus, improve eating behaviors more than dining with friends and, possibly, dining alone. Therefore, family dining could play a protective role against some forms of nutritional risk taking.

However, a few points must still be verified. First, the protective role of family dining as opposed to dining alone $(\mathrm{H} 1)$ requires further investigation, as the corresponding results are not indisputably significant. Second, only intentions (and not actual consumption patterns) were tested, which potentially biased the experiment if people understood the purpose of the study. Third, only home dining conditions were considered. It would be interesting to verify whether family dining's protective role against sweet food consumption, which Study 1 appears to show for dining at home, still holds for dining away from home. For all of these reasons, a second study was conducted on the basis of a descriptive survey.

\section{STUDY 2: HOW DINING AT HOME OR AWAY FROM HOME CHANGES THE}

\section{EFFECTS OF FAMILY AND FRIENDS ON SWEET FOOD CONSUMPTION}

According to Study 1, the intention to eat an unhealthy dessert at home seems to be smaller when dining with immediate family members than when dining alone (H1) or with friends (H2). Are these results valid under real conditions? To address this question, $\mathrm{H} 1$ and $\mathrm{H} 2$ were tested through a second study that involved asking the respondents about their actual dessert consumption habits (Study 2). 
Since out-of-home food consumption is on the rise around the world, ${ }^{4}$ the survey also investigated whether the effects of family members are similar in an out-of-home environment. Dining at home provides access to endo-cooking as opposed to exo-cooking. Endo-cooking refers to the intimate food habits of a clan (Corbeau and Poulain 2008), while exo-cooking refers to food displayed to the outside world (Corbeau and Poulain 2008). In this respect, while Study 1 refers to endo-cooking, Study 2 compared two different levels of intimacy: at-home dining vs. dining away from home, as food sociology underscores that physical space shapes social space (Fischler 2011).

Away from home, people usually feel less secure than they do at home with their families. For this reason, many people are reluctant to eat out alone: In many cultures, this is "frowned upon," and people dining alone have a lower sense of subjective well-being than when they eat in a group (Fischler 2011). As a result, people tend to avoid such situations and prefer to dine at restaurants with companions. Still, few studies have investigated the influence of companions on food consumer behavior. From the literature on service experiences, the presence of companions when visiting museums (Debenedetti 2003), shopping in malls (Chebat, Haj-Salem, and Oliveira 2014; Hart and Dale 2014), or eating at restaurants (Hart and Dale 2014) increases the amount of time and money spent, as well as satisfaction levels. Such effects are more significant for restaurant experiences than for pure shopping experiences (Hart and Dale 2014), illustrating that "companion" etymologically refers to "one who breaks bread with another" (Fischler 2011). This positive role of joint experiences can be attributed to cognitive and emotional support that reduces stress and emphasizes recreation (Debenedetti 2003). In the case of mall experiences, friends have a stronger influence than family members as shopping companions, as the former inspire stronger levels of shopping

4. It accounts for $20 \%$ of total food consumption, according to a study the Kantar World Panel (https://www.kantarworldpanel.com/global/News/New-report-out-Out-of-home-out-of-mind) did in Brazil, China, France, Indonesia, Mexico, Portugal, Spain, Thailand, and the UK. In France, the previously cited INCa3 report found the same figure: $80 \%$ of global food consumption is done at home, and more than $90 \%$ of dinners are had at home. 
arousal but also shopping apprehension because the shopper worries about being judged in terms of social acceptance (Chebat, Haj-Salem, and Oliveira 2014). To the best of the authors' knowledge, the effects of various types of companions have not been investigated in the case of out-of-home dining.

Dining away from home with one's family is not a familiar setting and disturbs the routine process (Chebat, Haj-Salem, and Oliveira 2014). People may feel tempted to treat themselves and their family members because it is exceptional to sit together as a family for lunch or dinner away from home. As a result, such a situation becomes a celebratory event, a "gift giving" case in Belk's 2010 typology, and no longer a matter of pure sharing. Therefore, the role that one's family plays regarding nutritional choices should be weaker than it is at home, thereby limiting impression management requirements (Herman, Roth, and Polivy 2003). Accordingly, the protective role that one's family plays in choices related to nutrition should be weaker away from home than at home. It could even lead people to take an indulgent dessert "for once" and cause others to do the same through the modeling effect (De Castro 2010).

- H3: When sharing a meal with one's family, the intention to consume indulgent sweet desserts is greater away from home than at home.

The model tested is summarized in Figure 1.

[Insert Figure 1 about here]

Methods of Study 2

In order to test all three hypotheses, Study 2 is based on real consumption behaviors. People were recruited using snowball sampling. A questionnaire was sent to the authors' social network, which the respondents forwarded to their own network. People were asked to 
provide information about two meals (either lunches or dinners) they had had the previous week - one at home and one away from home. These two conditions were presented in random order. The survey stressed that the participants should not consider a festive dinner and specifically ruled out celebratory events. After remembering each specific meal (one at and one away from home), the participants had to describe each meal's context (dining alone, with immediate family members, or with friends; watching TV or using another electronic device; reading or not reading). They were then asked: "During this meal, did you eat any of the following, and if yes, how do you evaluate them?" with a list of items corresponding to a typical French meal (starter, main dish, cheese/yoghurt, dessert). For each of them, they had to tick one of the following eight boxes: "No, I didn't eat any of it" (coded zero) or "Yes, I ate some and considered it...," followed by a seven-point Likert scale ranging from "very light" to "very heavy/very indulgent." Because the questionnaire asked the interviewees to evaluate the whole meal and not just the dessert, it limited the risk of the interviewees correctly guessing what the focus of the research is.

In total, 497 respondents answered the questions on at-home dining, and $80 \%$ of them (396) filled in the part regarding a meal they had had away from home the previous week. Table 4 presents the sample's demographic profile. The snowball sampling recruitment produced an overrepresentation of certain categories - in particular, those with high levels of education. Still, in Study 1, these covariates did not influence the intention to eat indulgent sweet desserts. Further analyses are conducted later to assess the incidence of these covariates in Study 2.

[Insert Table 4 about here] 


\section{Results of Study 2}

The dependent variable (consumption of an indulgent sweet dessert measured on a sevenpoint Likert scale) is based on six different dining conditions: home alone, at home with one's family, at home with friends, alone away from home, with family away from home, and with friends away from home (see Table 1). An ANOVA tested the effects of meal sharing on the consumption of indulgent sweet desserts based on dining locations (see Table 5).

[Insert Table 5 about here]

It must first be noted that, overall, the participants rated their sweet food consumption levels to be rather low. However, there were significant differences among the social contexts in question. In line with Study 1, the ANOVA results reveal a significant influence of meal conditions on sweet food consumption for dining at home $\left(M_{\text {family at home }}=2.06, M_{\text {alone at }}\right.$ home $\left.=2.60, M_{\text {friends at home }}=3.61, F=14.04, p=.001 * * *\right)$. Planned contrasts investigated where the differences are. The results confirm that at-home family dining involves less consumption of indulgent sweet desserts than when dining alone $(t(494)=1.96, p=.050 *)$, supporting H1. The findings also show that sharing meals at home with one's family involves less consumption of indulgent sweet dessert than when dining with friends $\left(t(494)=5.14, p=.001^{* * *}\right)$, supporting $\mathrm{H} 2$.

By contrast, the levels of indulgent sweet dessert consumption for dining away from home do not vary significantly among the three sharing-meal conditions $\left(M_{\text {family outside of the home }}=2.97\right.$, $\left.M_{\text {alone outside of the home }}=2.35, M_{\text {friends outside of the home }}=2.68, F=1.39, p=.250\right)$. Moreover, the results reveal significantly higher levels of sweet food consumption for family dining away from home than for family dining at home $\left(M_{\text {family outside of the home }}=2.97, M_{\text {family at home }}=2.06, F=11.63\right.$, $p=.001^{* * *}$. These results support $\mathrm{H} 3$ : The protective role of family dining is limited to consumption at home and does not hold outside the home. 
ANCOVAs were conducted to assess the influence of other covariates. There was no significant relationship between gender $(p=.540)$, age $(p=.847)$, household size $(p=.146)$, home region $(p=.506)$, or socio-economic level $(p=.452)$ and the consumption of sweet dessert for meals at home (as a reminder, ANOVAs were not significant for meals away from home). Eating in front of a screen, a book, or a newspaper (or not) did not change the results either $(p=.331)$. Similarly, whether people eat at home or away from home, with family or with friends, these variables do not influence the choice of dessert. With regard to the influence of the level of education, it was not significant at a $95 \%$ level, but it was at a $90 \%$ level $(p=.069)$. An important factor was whether people lived in a big city, a small city, or the countryside $(p=.059)$. It seems the bigger the city in which people live, the less they eat indulgent sweet desserts. This finding means it is crucial for future research to consider the influence of the size of people's town/city on their sweet food consumption.

Finally, an interesting result concerns the type of meal (lunch or dinner) when people eat with friends as opposed to when they eat with their family (see Table 6). Two-way independent ANOVAs show that when people eat with friends, the moderating factor is not whether they had the meal at home or away from home but whether it was lunch or dinner. The dessert chosen at dinnertime is more indulgent than the one chosen at lunch, regardless of whether it is at home $\left(M_{\text {dinner }}=4.04>M_{\text {lunch }}=2.89\right)$, away from home $\left(M_{\text {dinner }}=4,05>\right.$ $\left.M_{\text {lunch }}=2.50\right)$, or in total $\left(M_{\text {dinner }}=4.04>M_{\text {lunch }}=2.61\right)$, with a high level of significance $\left(F=6.51, p=.000^{* * *}\right)$. The effect of the meal location is not significant, nor is the inter-effect of meal location and type of meal.

It is the other way around for meals had with the family: The moderating factor is whether the meal was eaten at home or not, not whether it was lunch or dinner. The dessert chosen away from home is more indulgent than the dessert chosen at home, be it at lunchtime $\left(M_{O O H}=3.15>M_{\text {home }}=2.28\right)$, dinnertime $\left(M_{O O H}=2.85>M_{\text {home }}=2.03\right)$, or in total $\left(M_{O O H}=2.97>\right.$ 
$\left.M_{\text {home }}=2.07\right)$, with a high level of significance $(F=4.14, p=.007 * *)$. The effect of the type of meal is not significant, nor is the inter-effect of meal location and type of meal.

[Insert Table 6 about here]

\section{DISCUSSION}

Family dining tends to favor healthier behaviors at home by restricting sweet food consumption, as shown with an experiment (Study 1) and a descriptive survey (Study 2). Indeed, as Belk (2010) underlined, family meals at home entail caring and nurturing. As such, they are pure acts of sharing. But these findings also confer an educational responsibility upon the family and sets social norms during family meals. As a consequence, people feel they are being observed and evaluated according to these social norms. Thanks to the principles of impression management (Herman, Roth, and Polivy 2003), they tend to better control their food intake habits. This is amplified by modeling the others' behavior (Cruwys, Bevelander, and Hermans 2015; McFerran et al. 2013; Vartanian et al. 2015).

However, the protective role of the family does not hold in cases of eating away from home. Indeed, at-home dining habits relate to the intimacy of one's family, whereas dining away from home exposes people to strangers who do not belong to their clans (Corbeau and Poulain 2008). This changes the rules of the game. In the outside world, the family does not protect individuals as much from nutritionally risky behaviors: The routine is disturbed, people are taken out of their ordinary routines, and the family's normative roles become less necessary and apparent. On the contrary, because it is an unusual situation, it becomes a celebratory event and no longer a matter of pure sharing. As a result, the family is in a giftgiving situation, which makes the situation similar to when people receive friends at home: They display generosity and set educational food norms aside. The protective role of family dining is then limited to consumption at home. 
By contrast, when dining with their friends, people allow themselves to eat less healthily. As per Belk's (2010) typology, this is no longer an act of pure sharing as in the case of family meals but rather an act of gift giving (if this is a celebration event) or of sharing out (if this is a matter of dividing food between friends, as in the scenario used in the experiment). In both cases, and unlike with family meals, there are no longer any educational norms at stake. The social norm is to demonstrate generosity and to focus on pleasure. The principles of impression management (Herman, Roth, and Polivy 2003) should then lead to showing in return how people enjoy the moment in general and the food in particular. This is emphasized by social facilitation, since food is more special, the meals last longer, and people tend to focus on the exchanges with others rather than nutritional rules (Bell and Pliner 2003; De Castro 2010; Hetherington et al. 2006; Pliner et al. 2006; Stroebele and De Castro 2004). This process is again reinforced by modeling others' behavior (Vartanian et al. 2015).

Unlike family dining, when people eat with their friends, the moderating factor is no longer the meal location (at home or away from home) but the type of meal. Study 2 showed that people had more indulgent desserts for dinner than for lunch. This is most probably because some of the meals were had during the week, and people had to get back to work in the afternoon. They had a limited time available to eat, and they probably chose not to eat too indulgently so as to be more active in the afternoon. By contrast, for dinner they had time to relax and enjoy the moment. Having a dessert then could even be a way to extend the meal and thus the socialization process without looking impolite, particularly in restaurants where people feel they need to leave once they have finished eating. This led to them eating more indulgently through social facilitation and by modeling others' behavior. 


\section{Theoretical Contributions}

By connecting social facilitation, impression management, and modeling theories with the sharing typology that Belk (2010) developed, this research helps explain apparent contradictions in the literature on how the presence of others influences food intake patterns. According to Belk (2010), it is critical to take the sharing forms into account when studying consumer behavior. Doing so helped us analyze the differences in food consumption behavior based on the context of commensality. We found that food consumption behaviors vary depending on whether the meal is an act of "pure sharing" (family meals at home), "gift giving" (family meals away from home or celebration with friends) or "sharing out" (sharing one's dessert with friends unexpectedly coming over), as per Belk's (2010) typology.

In this sense, although Durkheim denied this (Fischler 2011), eating is a social act because behaviors do change when they are observed by others. Thus, this research adds to the "growing body of academic and policy research" on how the eating environment can influence consumers' food choices (Harris and Thomas 2017). It confirms the major role of Belk's (1975) situational factors - namely physical and social surroundings - in food behaviors. Furthermore, it shows the interaction of physical and social surroundings: Dining with one's family at home or away from home does not have the same effect on the consumption of indulgent sweet food.

\section{Implications for Policy and Business Stakeholders}

In terms of consumer health, this study has implications for both policy and business stakeholders, including health agencies, public authorities, food and catering industries, and food distributors. Indeed, it explains why providing an individual with nutritional information is not sufficient to foster healthier food behavior and thereby prevent obesity and other nutrition-related NCDs, which are the leading causes of death in the world. One must take 
into account with whom and where people eat because physical and social surroundings influence eating behaviors.

This finding calls into question the premise of a widely used model of public policy called the "knowledge, attitudes, beliefs, and practices" model (WHO 1990). The KABP model suggests a linear relationship between individual nutritional knowledge and behavior improvement: Knowledge influences attitudes, which affect beliefs, which, in turn, eventually change practices. Thus, increasing nutritional knowledge levels should improve eating behaviors. But the present research shows it is not sufficient: Public policies should also take into account the dining context. In particular, they should encourage at-home family dining, which nudges people toward eating less indulgent sweet desserts. It could also contribute to fighting childhood obesity, as previous research has shown that parents have an influence on their children's eating behavior (Stutts et al. 2011). We could expect that children regularly dining with their parents eat less sugar, provided their parents know the basic dietary rules. Indeed, the pure sharing act of family dining sets social norms, which individuals tend to abide by, as they feel judged by their family. As a consequence, they tend to choose healthier options.

Public authorities could also encourage meal sharing in contexts outside the family environment by creating proper sharing conditions. Canteens in organizations dedicated to education, like schools and universities, are a good place to start. Since they are highly subsidized, it is easy to position them as a sharing case rather than gift giving or sharing out, particularly in school canteens with table service, as to induce impression management rather than social facilitation. Moreover, these organizations are in a legitimate position to set social norms of food education. If canteens succeed in recreating the context and atmosphere of family meals, pupils and students should be able to comply with these norms more easily. 
Companies could do the same. Even though they do not have the same legitimacy as schools or universities in terms of education, they do play a social role in society. As part of their corporate social responsibility program, they could take on the traditionally parental role and try to replicate family meals in their own canteens if they have some. If they do not, they could be encouraged to create shared canteens with surrounding companies. Alternatively, smaller companies could assign a specific room to lunch, decorate it to look like a home dining room, and encourage their employees to take their lunch breaks there, along with their colleagues. It would help push back against the ongoing trend of ever shorter lunch breaks, with people eating on the go or alone in front of their computer. It would also reinforce the bonds between employees.

In the same vein, we could imagine "meal pooling applications" for people who do not want to eat alone at home. Such digital platforms might connect people who are ready to share their meal with others, based on criteria such as type of food, food healthiness, location, number of guests, and socio-demographic profile.

Thus, fostering meal sharing in the shape of a family meal could help fight nutritional diseases by nudging people toward eating more healthily.

Moreover, actions could be taken to encourage people not to have indulgent desserts when having dinner with friends, or when eating out with their family - two situations which foster high-calorie sweet food consumption. We saw that having a dessert is also a way to extend the time spent together. But many restaurants only offer indulgent desserts on their menu. A way to promote healthier eating would be to include desserts in the form of aesthetically appealing "fruit arrangements" to be shared among guests. This would extend socialization, while presenting fruit as a treat and making it a case of "gift giving" in Belk's (2010) typology. Similarly, we could envision stores offering decorative "fruit arrangements" to bring along when invited by friends as an alternative to indulgent desserts or chocolates. Thus, social 
models would be used to promote the consumption of healthy foods, in line with Vartanian et al. (2015)'s recommendations.

\section{Limitations and Directions for Future Research}

More research is needed to confirm these results' applicability to other cultural contexts. For example, food is more socially bound in France than it is in the United States (Pollan 2009; Rozin et al. 1999). As noted above, family dining is the norm in France (Hébel 2012), whereas Americans are eating alone more and more often (Fischler and Masson 2008; Pollan 2009; Sobal and Nelson 2003). Using US panel data, Popovich (2017) studied the relationships between environment, diet, behaviors, and socio-demographics on calorie intake, but the data did not include dining conditions. Still, as the author pointed out, "eating at home versus dining out is an informative factor to consider when examining consumption patterns." Thus, it would make sense to investigate whether family dining protects against nutritional risk taking in the USA as well. This might not be the case, as research on values reveals the importance of the axis of "collective vs. individual concerns" (Bech-Larsen and Grunert 2003; B. Schwartz et al. 2002; S. H. Schwartz and Boehnke 2004; Torelli et al. 2012). Another interesting area of research is Asia, where food plays a central role in different cultures (Seo, Cruz, and Fam 2015). In particular, China's collectivist culture assigns a strong role to family meals, while many urban consumers now have to eat away from home because of their busy schedules (Yu, Veeck, and Yu 2015). In China, similar experiments and surveys would be useful to assess the influence of more individualized eating habits on nutritional risk taking as opposed to having family meals at home.

Another limitation of the study is the use of self-reported accounts rather than observational data. This calls for further research based on different research designs (e.g., observation). 
In terms of future research, it would be interesting to investigate the socialization process in greater depth. Some studies have pointed to the effects of school lunch programs (Schanzenbach 2009) and the number of nearby fast-food outlets (Newman, Howlett, and Burton 2014) on obesity levels among children. Another research avenue could include verifying the conditions under which children eat at home with their families (or not) and what types of families are involved (e.g., a single-parent struggling to balance time and money or a more secure family context). In light of the present research, the size of the city or town in which people live might also have an influence on the amount of sugar eaten; it would be interesting to take this parameter into account.

Future research could also focus on the influence of the social context on other forms of food consumption (e.g., fatty and salty foods or alcohol consumption). There would be an interest in testing whether the same pattern applies, with at-home family dining limiting intentions to consume and with meal sharing at home with friends promoting them. Such research could focus on other settings (e.g. canteens), festive occasions (e.g. Thanksgiving in the USA, as an extension of Wallendorf and Arnould 1991), or consuming restaurant food at home, a trend that is growing thanks to the emergence of services such as Uber Eats and its competitors. It would be useful to take into account people's food consumption goals, which differ according to whether they tend to obey or disobey nutrition rules and have a positive or negative-to-neutral approach to food (Chalamon and Nabec 2016). Further research could also include the possible influence of people's knowledge and motivation regarding food and nutrition (Hieke and Taylor 2012), as well as their health motivations and food values (Luomala et al. 2015).

Finally, a more holistic approach to food seems necessary to improve populations' eating behaviors, promoting an art de vivre for food rather than a sole focus on nutrition in accordance with the "food well-being paradigm" (Block et al. 2011; Bublitz et al. 2013). 


\section{REFERENCES}

Ajzen, Icek. 1991. The Theory of Planned Behavior. Organizational Behavior \& Human Decision Processes, 50 (2): 179-211.

Ajzen, Icek, and Martin Fishbein. 1980. Understanding Attitudes and Predicting Social Behavior. Englewood Cliffs, NJ: Prentice-Hall.

Allen-O'Donnell, Molly, Marci D. Cottingham, Thomas C. Nowak, and Kay A. Snyder. 2011. Impact of Group Settings and Gender on Meals Purchased by College Students. Journal of Applied Social Psychology, 41 (9): 2268-83.

Bandura, Albert. 1977. Self-Efficacy: Toward a Unifying Theory of Behavioral Change. Psychological Review, 84 (2): 191-215.

Bech-Larsen, Tino, and Klaus G Grunert. 2003. The Perceived Healthiness of Functional Foods. Appetite, 40 (1): 9-14.

Belk, Russell. 2010. Sharing. Journal of Consumer Research, 36 (5): 715-34.

Bell, Rick, and Patricia L. Pliner. 2003. Time to Eat: The Relationship between the Number of People Eating and Meal Duration in Three Lunch Settings. Appetite, 41 (2): 215-18.

Block, Lauren G., Sonya A. Grier, Terry L. Childers, Brennan. Davis, Jane E. J. Ebert, Shiriki Kumanyika, Russell N. Laczniak, et al. 2011. From Nutrients to Nurturance: A Conceptual Introduction to Food Well-Being. Journal of Public Policy \& Marketing, 30 (1): $5-13$.

Boutaud, Jean-Jacques. 2004. L'imaginaire de la table: convivialité, commensalité et communication. Paris: L’Harmattan.

Bublitz, Melissa G., Laura A. Peracchio, Alan R. Andreasen, Jeremy Kees, Blair Kidwell, Elizabeth Gelfand Miller, Carol M. Motley, et al. 2013. Promoting Positive Change: 
Advancing the Food Well-Being Paradigm. Journal of Business Research, 66 (8): 121118.

Burton, Scot, Andrea H. Tangari, Elizabeth Howlett, and Anna M. Turri. 2014. How the Perceived Healthfulness of Restaurant Menu Items Influences Sodium and Calorie Misperceptions: Implications for Nutrition Disclosures in Chain Restaurants. Journal of Consumer Affairs, 48 (1): 62-95.

Chalamon, Isabelle, and Lydiane Nabec. 2016. Why Do We Read On-Pack Nutrition Information so Differently? A Typology of Reading Heuristics Based on Food Consumption Goals. Journal of Consumer Affairs, 50 (2): 403-29.

Chebat, Jean-Charles, Narjes Haj-Salem, and Sandra Oliveira. 2014. Why Shopping Pals Make Malls Different? Journal of Retailing \& Consumer Services, 21 (2): 77-85.

Corbeau, Jean Pierre, and Jean-Pierre Poulain. 2008. Penser l'alimentation : entre imaginaire et rationalité. Toulouse: Privat.

Cruwys, Tegan, Kirsten E. Bevelander, and Roel C. J. Hermans. 2015. Social Modeling of Eating: A Review of When and Why Social Influence Affects Food Intake and Choice. Appetite, 86 (March): 3-18.

De Castro, John M. 2010. The Control of Food Intake of Free-Living Humans : Putting the Pieces Back Together. Physiology \& Behavior, 100 (5): 446-53.

Debenedetti, Stéphane. 2003. L'expérience de Visite Des Lieux de Loisirs: Le Rôle Central Des Compagnons. Recherche et Applications en Marketing, 18 (4): 43-58.

Dobbs, Richard, Corinne Sawers, Fraser Thompson, James Manyika, Jonathan Woetzel, Peter Child, Sorcha McKenna, and Angela Spatharou. 2014. How the World Could Better Fight Obesity. In McKinsey Global Institute. http://www.mckinsey.com/industries/healthcaresystems-and-services/our-insights/how-the-world-could-better-fight-obesity. 
Dubé, Laurette, Jordan L. LeBel, and Ji Lu. 2005. Affect Asymmetry and Comfort Food Consumption. Physiology \& Behavior, 86 (4): 559-67.

Fischler, Claude. 2011. Commensality, Society and Culture. Social Science Information, 50 (3-4): 528-48.

- 2013. Les Alimentations particulières: Mangerons-nous encore ensemble demain? Paris: Odile Jacob.

Fischler, Claude, and Estelle Masson. 2008. Manger: Français, Européens et Américains Face à l'alimentation. Paris: Odile Jacob.

Fishbein, Martin, and Icek Ajzen. 1975. Belief, Attitude, Intention and Behavior: An Introduction to Theory and Research. Boston: Addison-Wesley Publishing.

Grunert, Klaus G., and Josephine M. Wills. 2007. A Review of European Research on Consumer Response to Nutrition Information on Food Labels. Journal of Public Health, 15 (5): 385-99.

Harris, Judy, and Veronica L. Thomas. 2017. The Influence of Bundling and Caloric Knowledge on Calories Ordered and Purchase Intent. Journal of Consumer Affairs, 51 (1): $113-32$.

Hart, Phillip M., and Rick Dale. 2014. With or without You: The Positive and Negative Influence of Retail Companions. Journal of Retailing \& Consumer Services, 21 (5): 78087.

Hassan, Louise M., Edward M. K. Shiu, and Nina Michaelidou. 2010. The Influence of Nutrition Information on Choice: The Roles of Temptation, Conflict and Self-Control. Journal of Consumer Affairs, 44 (3): 499-515.

Hawley, L., D. Harker, and M. Harker. 2010. A Social Cognitive Approach to Tackle Inactivity and Obesity in Young Australians. Journal of Business Research, 63 (2): 11620. 
Hébel, Pascale. 2012. Comportements et Consommations Alimentaires En France. Lavoisier Tec \& Doc. Paris.

Herman, C. Peter, Deborah A. Roth, and Janet Polivy. 2003. Effects of the Presence of Others on Food Intake : A Normative Interpretation. Psychological Bulletin, 129 (6): 873-86.

Hetherington, M, A Anderson, G Norton, and L Newson. 2006. Situational Effects on Meal Intake: A Comparison of Eating Alone and Eating with Others. Physiology \& Behavior, 88 (4-5): 498-505.

Hieke, Sophie, and Christopher L. Newman. 2015. The Effects of Nutrition Label Comparison Baselines on Consumers' Food Choices. Journal of Consumer Affairs, 49 (3): 613-26.

Hieke, Sophie, and Charles R. Taylor. 2012. A Critical Review of the Literature on Nutritional Labeling. Journal of Consumer Affairs, 46 (1): 120-56.

Kantar TNS. 2012. Les Desserts Préférés Des Français. Gourmand, 14 2012. http://www.tnssofres.com/publications/les-desserts-preferes-des-francais.

Laporte, Marie-Eve, Géraldine Michel, and Sophie Rieunier. 2015. Toward a Better Understanding of Eating-Behaviour through the Concept of Perception of Nutritional Risk. Recherche et Applications en Marketing, 30 (1): 1-37.

Luomala, Harri, Maijastiina Jokitalo, Hannu Karhu, Hanna-Leena Hietaranta-Luoma, Anu Hopia, and Sanna Hietamäki. 2015. Perceived Health and Taste Ambivalence in Food Consumption. Journal of Consumer Marketing, 32 (4): 290-301.

Masson, Estelle, Sandrine Bubendorff, and Christèle Fraïssé. 2018. Toward New Forms of Meal Sharing? Collective Habits and Personal Diets. Appetite, 123 (April): 108-13.

Mathé, Thierry, Aurée Francou, Justine Colin, and Pascale Hébel. 2011. Comparaison Des Modèles Alimentaires Français et États-Uniens. Cahier de recherche 253. Paris: Crédoc. 
Mauss, Marcel. 1925. The Gift: Forms and Functions of Exchange in Archaic Societies. Mansfield Centre, CT: Martino Fine Books (éd. 2011).

McFerran, Brent, Darren W. Dahl, Gavan J. Fitzsimons, and Andrea C. Morales. 2013. I'11 Have What She's Having: Effects of Social Influence and Body Type on the Food Choices of Others. Journal of Consumer Research, 36 (6): 915-29.

Mintz, Sidney W., and Christine M. Du Bois. 2002. The Anthropology of Food and Eating. Annual Review of Anthropology, 31 (1): 99-119.

Moore, Elizabeth S, and Victoria J Rideout. 2007. The Online Marketing of Food to Children : Is It Just Fun and Games? Journal of Public Policy \& Marketing, 26 (2): 20220.

Mori, DeAnna, Shelly Chaiken, and Patricia Pliner. 1987. 'Eating Lightly' and the SelfPresentation of Femininity. Journal of Personality and Social Psychology, 53 (4): 693702.

Moss, Michael. 2013. Salt, Sugar, Fat: How the Food Giants Hooked Us. New York: Random House.

Nayga, Rodolfo M. 2000. Nutrition Knowledge, Gender, and Food Label Use. Journal of Consumer Affairs, 34 (1): 97-112.

Newman, Christopher L., Elizabeth Howlett, and Scot Burton. 2014. Implications of Fast Food Restaurant Concentration for Preschool-Aged Childhood Obesity. Journal of Business Research, 67 (8): 1573-80.

Picq, Pascal. 2004. Imaginez: Quand Les Chimpanzés s'invitent à La Table de l'homme! In L'imaginaire de La Table: Convivialité, Commensalité et Communication, by JeanJacques Boutaud, 25-45. Paris: L'Harmattan. 
Pliner, Patricia, Rick Bell, Edward S. Hirsch, and Mark Kinchla. 2006. Meal Duration Mediates the Effect of 'Social Facilitation' on Eating in Humans. Appetite, 46 (2): 18998.

Pollan, Michael. 2009. In Defense of Food: An Eater's Manifesto. New York: Penguin Books.

Popovich, Deidre. 2017. Behavioral and Lifestyle Influences on Reported Calorie Intake: A Latent Class Model. Journal of Consumer Marketing, 34 (3): 214-25.

Poulain, Jean-Pierre. 2002. Sociologies de l'alimentation: Les Mangeurs et l'espace Social Alimentaire. Paris: Presses Universitaires de France.

- 2012. Dictionnaire Des Cultures Alimentaires. Paris: Presses Universitaires de France.

Povey, Rachel, Mark Conner, Paul Sparks, Rhiannon James, and Richard Shepherd. 2000. The Theory of Planned Behaviour and Healthy Eating: Examining Additive and Moderating Effects of Social Influence Variables. Psychology and Health, 14 (6): 9911006.

Rozin, Paul. 2005. The Meaning of Food in Our Lives: A Cross-Cultural Perspective on Eating and Well-Being. Journal of Nutrition Education \& Behavior, 37 (37): 107-12.

Rozin, Paul, Claude Fischler, Sonoka Imada, Allisson Sarubin, and Amy Wrzesniewski. 1999. Attitudes to Food and the Role of Food in Life in the U.S.A., Japan, Flemish Belgium and France : Possible Implications for the Diet-Health Debate. Appetite, 33 (2): 163-80.

Rozin, Paul, Kimberly Kabnick, Erin Pete, Claude Fischler, and Christy Shields. 2003. The Ecology of Eating. Psychological Science, 14 (5): 450.

Saint Pol, Thibaut de, and Layla Ricroch. 2012. Le Temps de l'alimentation En France. INSEE Première, 1417 (October). 
Saulais, Laure, Maurice Doyon, Bernard Ruffieux, and Harry Kaiser. 2012. Consumer Knowledge about Dietary Fats: Another French Paradox? British Food Journal, 114 (1): $108-20$.

Schanzenbach, Diane Whitmore. 2009. Do School Lunches Contribute to Childhood Obesity? Journal of Human Resources, 44 (3): 684-709.

Schwartz, Barry, Andrew Ward, Sonja Lyubomirsky, John Monterosso, Katherine White, and Darrin R. Lehman. 2002. Maximizing versus Satisficing: Happiness Is a Matter of Choice. Journal of Personality \& Social Psychology, 83 (5): 1178-97.

Schwartz, Shalom H, and Klaus Boehnke. 2004. Evaluating the Structure of Human Values with Confirmatory Factor Analysis. Journal of Research in Personality, 38 (3): 230-55.

Seo, Yuri, Angela Gracia B. Cruz, and Kim-Shyan Fam. 2015. Food Consumption and Marketing: Turning toward Asia. Journal of Consumer Marketing, 32 (7): 501-4.

Sobal, Jeffery, and Mary K. Nelson. 2003. Commensal Eating Patterns : A Community Study. Appetite, 41 (2): 181.

Stroebele, Nanette, and John M. De Castro. 2004. Effect of Ambience on Food Intake and Food Choice. Nutrition, 20 (9): 821-38.

Stutts, Mary Ann, Gail M. Zank, Karen H. Smith, and Sally A. Williams. 2011. Nutrition Information and Children's Fast Food Menu Choices. Journal of Consumer Affairs, 45 (1): 52-86.

Torelli, Carlos J, Ayşegül Özsomer, Sergio W Carvalho, Hean Tat Keh, and Natalia Maehle. 2012. Brand Concepts as Representations of Human Values : Do Cultural Congruity and Compatibility between Values Matter? Journal of Marketing, 76 (4): 92-108.

Troisi, Jordan D., and Shira Gabriel. 2011. Chicken Soup Really Is Good for the Soul: 'Comfort Food' Fulfills the Need to Belong. Psychological Science, 22 (6): 747-53. 
Troisi, Jordan D., Shira Gabriel, Jaye L. Derrick, and Alyssa Geisler. 2015. Threatened Belonging and Preference for Comfort Food among the Securely Attached. Appetite, 90 (July): 58-64.

Troisi, Jordan D., and Julian W. C. Wright. 2017. Comfort Food. Teaching of Psychology, 44 (1): 78-84.

Vartanian, Lenny R., Samantha Spanos, C. Peter Herman, and Janet Polivy. 2015. "Modeling of Food Intake: A Meta-Analytic Review.” Social Influence 10 (3): 119-36.

Wallendorf, Melanie, and Eric J. Arnould. 1991. 'We Gather Together': Consumption Rituals of Thanksgiving Day. Journal of Consumer Research, 18 (1): 13-31.

Wang, Jing, Rui (Juliet) Zhu, and Baba Shiv. 2012. The Lonely Consumer: Loner or Conformer? Journal of Consumer Research, 38 (6): 1116-28.

WHO. 1990. WHO Global Programme on AIDS: Social and Behavioural Research. World Health Organization Library, 14 (3): 276-281.

- 2013a. Global Nutrition Policy Review: What Does It Take to Scale up Nutrition Action? In World Health Organization Library. Geneva, Switzerland.

- 2013b. Vienna Declaration on Nutrition and Noncommunicable Diseases in the Context of Health 2020. July 5, 2013.

2015. Guideline: Sugars Intake for Adults and Children. Geneva, Switzerland: World Health Organization.

— 2017. Noncommunicable Diseases Fact Sheet. WHO. 2017. http://www.who.int/mediacentre/factsheets/fs355/en/.

WHO, and FAO. 2003. Diet, Nutrition and the Prevention of Chronic Diseases: Report of a Joint WHO/FAO Expert Consultation. In Technical Report Series. Vol. 916. Geneva, Switzerland: World Health Organization. 
Wood, Stacy. 2010. The Comfort Food Fallacy: Avoiding Old Favorites in Times of Change. Journal of Consumer Research, 36 (6): 950-63.

Yu, Hongyan, Ann Veeck, and Fang (Grace) Yu. 2015. Family Meals and Identity in Urban China. Journal of Consumer Marketing, 32 (7): 505-19.

Zingg, Alexandra, Marie-Eve Cousin, Melanie Connor, and Michael Siegrist. 2013. Public Risk Perception in the Total Meat Supply Chain. Journal of Risk Research, 16 (8): 100520. 
TABLES AND FIGURES

TABLE 1

Experimental design (Study 1)

\begin{tabular}{llll}
\hline $\begin{array}{l}\text { MEAL-SHARING } \\
\text { CONDITION }\end{array}$ & ALONE & WITH FAMILY & WITH FRIENDS \\
\hline $\begin{array}{l}\text { Study 1: typical } \\
\text { dinner at home }\end{array}$ & $\begin{array}{l}\text { Dining alone at } \\
\text { home }\end{array}$ & $\begin{array}{l}\text { Sharing a meal at } \\
\text { home with immediate } \\
\text { family members }\end{array}$ & $\begin{array}{l}\text { Sharing a meal at } \\
\text { home with unexpected } \\
\text { guests }\end{array}$ \\
\hline
\end{tabular}


TABLE 2

Respondents' profiles (Study 1)

\begin{tabular}{|c|c|c|c|c|c|c|}
\hline & & $\begin{array}{l}\text { Dining alone } \\
\text { at home }\end{array}$ & $\begin{array}{l}\text { Sharing a meal at } \\
\text { home with } \\
\text { immediate family } \\
\text { members }\end{array}$ & $\begin{array}{l}\text { Sharing a meal } \\
\text { at home with } \\
\text { unexpected } \\
\text { guests } \\
\end{array}$ & Total $^{(1)}$ & $\begin{array}{l}\text { Chi- } \\
\text { square } \\
\text { analysis }\end{array}$ \\
\hline \multirow{3}{*}{$\begin{array}{l}\text { Size of } \\
\text { household }\end{array}$} & 1 or 2 people & 32 & 16 & 24 & 72 & $\chi^{2}(2)=$ \\
\hline & 3 or more & 11 & 28 & 21 & 60 & 12.74, \\
\hline & Total & 43 & 44 & 45 & 132 & $p=.002 * *$ \\
\hline \multirow{4}{*}{$\begin{array}{l}\text { Level } \\
\text { of education }\end{array}$} & Low & 10 & 14 & 8 & 32 & $\chi^{2}(4)=$ \\
\hline & Middle & 18 & 24 & 27 & 69 & 7.51, \\
\hline & High & 15 & 6 & 10 & 31 & $p=.111$ \\
\hline & Total & 43 & 44 & 45 & 132 & \\
\hline \multirow{3}{*}{$\begin{array}{l}\text { Home } \\
\text { location }\end{array}$} & Countryside & 26 & 32 & 29 & 87 & $\chi^{2}(2)=$ \\
\hline & City & 17 & 12 & 16 & 45 & 1.52 \\
\hline & Total & 43 & 44 & 45 & 132 & $p=.468$ \\
\hline \multirow[t]{3}{*}{ Area } & Paris region & 11 & 6 & 6 & 23 & $\chi^{2}(2)=$ \\
\hline & Province & 32 & 38 & 39 & 109 & 2.95, \\
\hline & Total & 43 & 44 & 45 & 132 & $p=.229$ \\
\hline \multirow[t]{6}{*}{$\overline{\text { Age }}$} & $25-34$ & 7 & 8 & 18 & 33 & $\chi^{2}(4)=$ \\
\hline & $35-49$ & 16 & 18 & 13 & 47 & 8.49 , \\
\hline & 50 and over & 20 & 18 & 14 & 52 & $p=.075$ \\
\hline & Average & 47.7 & 45.3 & 41.3 & 44,7 & \\
\hline & SD & 12.87 & 11.20 & 11.10 & 11.90 & \\
\hline & Total & 43 & 44 & 45 & 132 & \\
\hline \multirow{2}{*}{$\begin{array}{l}\text { Socio- } \\
\text { professional } \\
\text { category }\end{array}$} & Higher & 29 & 31 & 34 & 94 & $\chi^{2}(2)=$ \\
\hline & Lower & 14 & 13 & 11 & 38 & $\begin{array}{r}.725 \text {, } \\
p=.696\end{array}$ \\
\hline
\end{tabular}

$* p<.05 ; * * p<.01 ; * * * p<.001$

${ }^{(1)} \mathrm{NB}$ : The information is missing from two of the 134 questionnaires. 
TABLE 3

Intentions to eat chocolate mousse for each meal-sharing condition (Study 1)

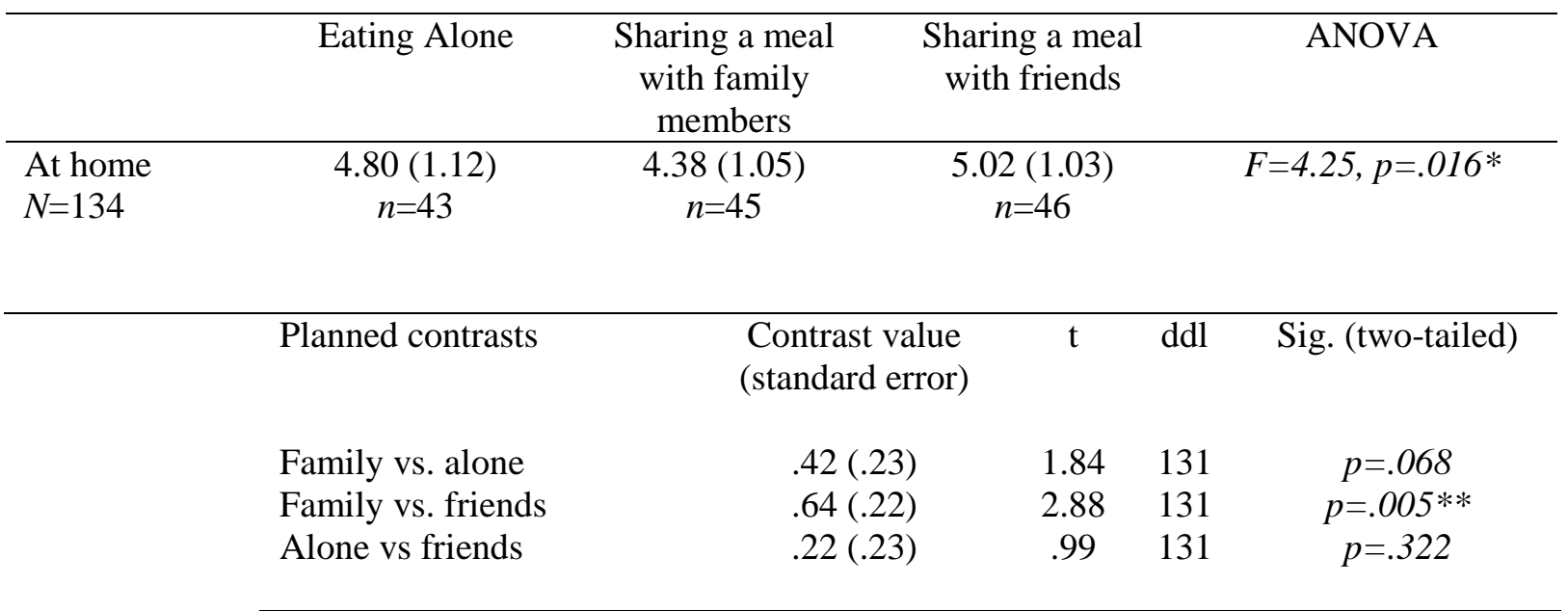

$* p<.05 ; * * p<.01 ; * * * p<.001$ 
TABLE 4

Respondents' profiles (Study 2)

\begin{tabular}{|c|c|c|c|c|}
\hline \multirow[t]{3}{*}{ Gender } & Men & 104 & 102 & 206 \\
\hline & Women & 292 & 290 & 582 \\
\hline & Total & 396 & 392 & 788 \\
\hline \multirow[t]{2}{*}{ Age } & Average & 38.49 & 38.54 & 38.51 \\
\hline & (standard deviation) & $(12.15)$ & $(12.12)$ & $(12.13)$ \\
\hline \multirow[t]{6}{*}{ Size of household } & 1 person & 81 & 79 & 160 \\
\hline & 2 & 111 & 107 & 218 \\
\hline & 3 & 70 & 71 & 141 \\
\hline & 4 & 86 & 88 & 174 \\
\hline & 5 or more & 49 & 48 & 97 \\
\hline & Total & 397 & 393 & 790 \\
\hline \multirow{3}{*}{$\begin{array}{l}\text { Level } \\
\text { of education }\end{array}$} & Lower & 41 & 41 & 82 \\
\hline & Higher & 356 & 352 & 708 \\
\hline & Total & 397 & 393 & 790 \\
\hline \multirow{5}{*}{$\begin{array}{l}\text { Socio-professional } \\
\text { category }\end{array}$} & Employee level & 120 & 129 & 239 \\
\hline & Executive level & 215 & 211 & 426 \\
\hline & Students & 39 & 39 & 78 \\
\hline & Not working & 19 & 20 & 39 \\
\hline & Total & 393 & 389 & 782 \\
\hline \multirow[t]{3}{*}{ Area } & Paris region & 248 & 247 & 495 \\
\hline & Rest of France & 145 & 142 & 287 \\
\hline & Total & 393 & 389 & 782 \\
\hline \multirow[t]{3}{*}{ Home location } & Countryside or small city & 128 & 130 & 258 \\
\hline & City $\geq 50000$ inhabitants & 265 & 259 & 524 \\
\hline & Total & 393 & 389 & 782 \\
\hline
\end{tabular}


TABLE 5

Consumption of sweet dessert for each meal-sharing and location condition (Study 2)

\begin{tabular}{|c|c|c|c|c|c|}
\hline $\begin{array}{l}\text { All } \\
\text { respondents } \\
(N=893)\end{array}$ & Eating alone & $\begin{array}{l}\text { Sharing a meal } \\
\text { with family } \\
\text { members }\end{array}$ & $\begin{array}{l}\text { Sharing a mea } \\
\text { with friends }\end{array}$ & & ANOVA \\
\hline $\begin{array}{l}\text { At home } \\
N=497\end{array}$ & $\begin{array}{c}2.60(2.79) \\
n=154\end{array}$ & $\begin{array}{c}2.06(2.10) \\
n=189\end{array}$ & $\begin{array}{c}3.61(3.19) \\
n=154\end{array}$ & & $F=14.04, p=.000 * * *$ \\
\hline $\begin{array}{l}\text { Away from } \\
\text { home } \\
N=396\end{array}$ & $\begin{array}{c}2.35(2.69) \\
n=84\end{array}$ & $\begin{array}{c}2.97(2.64) \\
n=135\end{array}$ & $\begin{array}{c}2.68(2.66) \\
n=177\end{array}$ & & $F=1.39, p=.250$ \\
\hline \multirow[t]{2}{*}{ ANOVA } & $F=.43, p=.51$ & $\begin{array}{c}F=11.63 \\
p=.001 * * *\end{array}$ & $\begin{array}{c}F=8.27 \\
p=.001 * * *\end{array}$ & & \\
\hline & $\begin{array}{l}\text { Family vs. alone } \\
\text { Family vs. friends } \\
\text { Alone vs. friends }\end{array}$ & $\begin{array}{c}\text { CONTRAST } \\
\text { VALUE } \\
\text { (STANDARD } \\
\text { ERROR) } \\
.53(.27) \\
1.54(.29) \\
1.01(.34)\end{array}$ & $\begin{array}{l}1.96 \\
5.14 \\
2.94\end{array}$ & $\begin{array}{l}279 \\
254 \\
301\end{array}$ & $\begin{array}{c}p=.050 * \\
p=.000 * * * \\
p=.004 * *\end{array}$ \\
\hline$* p<.05$ & & $* * p<.01$ & & & $* * * p<.0$ \\
\hline
\end{tabular}


TABLE 6

Influence of type and location of meal on consumption of sweet dessert (Study 2)

\begin{tabular}{|c|c|c|c|}
\hline & $\begin{array}{l}\text { Mean (standard deviation), } \\
\text { sample size } n\end{array}$ & $\begin{array}{l}\text { Sharing a meal with } \\
\text { family members }\end{array}$ & $\begin{array}{l}\text { Sharing a meal with } \\
\text { friends }\end{array}$ \\
\hline \multirow[t]{3}{*}{ At home } & Lunch & $2.28(2.27), n=32$ & 2.89 (3.21), $n=58$ \\
\hline & Dinner & $2.03(2.08), n=157$ & 4.04 (3.13), $n=96$ \\
\hline & Total & 2.07 (2.11), $n=189$ & 3.62 (3.19), $n=154$ \\
\hline \multirow{3}{*}{$\begin{array}{l}\text { Away from } \\
\text { home }\end{array}$} & Lunch & $3.15(2.82), n=55$ & 2.50 (2.45), $n=156$ \\
\hline & Dinner & $2.85(2.53), n=80$ & 4.05 (3.67), $n=21$ \\
\hline & Total & 2.97 (2.65), $n=135$ & $2.68(2.66), n=177$ \\
\hline \multirow[t]{3}{*}{ Total } & Lunch & $2.83(2.66), n=87$ & $2.61(2.68), n=214$ \\
\hline & Dinner & 2.30 (2.27), $n=237$ & $4 ; 04$ (3.21), $n=117$ \\
\hline & Total & 2.44 (2.38), $n=324$ & $3.11(2.96), n=331$ \\
\hline \multirow{4}{*}{$\begin{array}{l}\text { Two-way } \\
\text { independent } \\
\text { ANOVA }\end{array}$} & Total effect & $F=4.14, p=.007 * *$ & $\mathbf{F}=6.51, \mathbf{p}=.000 * * *$ \\
\hline & Meal location & $F=7.56, p=.006 * *$ & $\mathrm{~F}=.22, \mathrm{p}=.636$ \\
\hline & Meal type & $F=.805, p=.370$ & $\mathbf{F}=10.67, \mathbf{p}=.001 * * *$ \\
\hline & Meal type $\mathrm{x}$ meal location & $F=.004, p=.949$ & $\mathrm{~F}=.24, \mathrm{p}=.626$ \\
\hline
\end{tabular}


FIGURE 1

Model

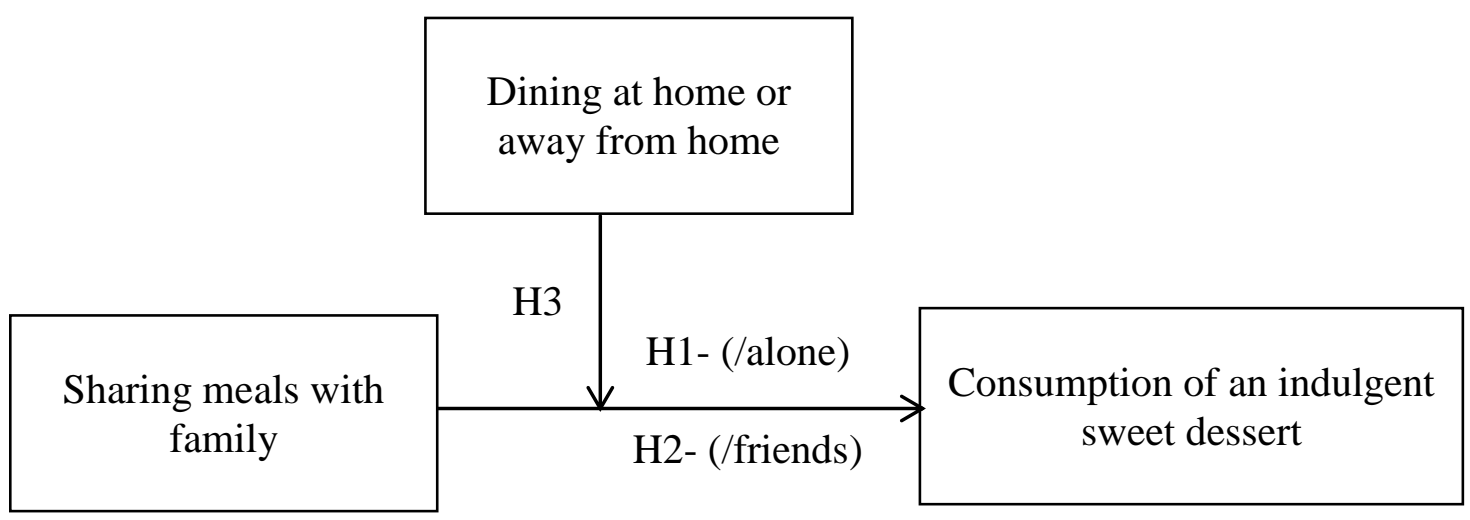

